Brazilian Journal

of Chemical

\title{
STUDY OF ANTIOXIDANT PROPERTY OF A THIOPHOSPHORATED COMPOUND DERIVED FROM CASHEW NUT SHELL LIQUID IN HYDROGENATED NAPHTHENICS OILS
}

\author{
A. A. S. Lopes ${ }^{1 *}$, E. A. Carneiro ${ }^{1}$, M. A. S. Rios ${ }^{2}$, J. J. Hiluy Filho², J. O. B. Carioca ${ }^{2}$, \\ G. G. Barros ${ }^{2}$ and S. E. Mazzetto ${ }^{2}$ \\ ${ }^{1}$ Departamento de Engenharia Química, Universidade Federal do Ceará, Campus do Pici, Bloco 709, \\ Fax: +(55) (85) 3244-0707, CEP: 60455-760, Fortaleza - CE, Ceará, Brazil. \\ E-mail: adasanders@gmail.com \\ ${ }^{2}$ Parque de Desenvolvimento Tecnológico, Universidade Federal do Ceará, \\ Avenida do Contorno s/n, Fortaleza - CE, Brazil.
}

(Received: January 24, 2007; Accepted: August 9, 2007)

\begin{abstract}
The present work shows the aspects related to the synthesis and thermogravimetric analysis of thiophosphorated and phosphorated compounds from hydrogenated cardanol. Studies on thermal-oxidative stability were investigated, using a classical thermoanalytical-thermogravimetric method (TG/DTG) in an air atmosphere. Its use as an antioxidant additive in hydrogenated naphthenic NH10, NH20 and NH140 oils was evaluated. The addition of $1.2 \%$ synthesized compounds to the oils has improved their thermal-oxidative stability by $5-15^{\circ} \mathrm{C}$. The occurrence of major thermal degradation events at higher temperatures $\left(\mathrm{T}_{\max }\right)$ in additivated oils is a good indication of the antioxidant properties of the thiophosphorated and phosphorated cardanol compounds antioxidant properties.
\end{abstract}

Keywords: CNSL; Thiophosphorated compound; Antioxidant.

\section{INTRODUCTION}

Sulphur-phosphorus compounds have been used as antiwear additives (Bansal, et. al., 2002) and antioxidants (Lopes, 2005) in mineral based oils. The oxidation stability and performance of these additives is dependent upon the chemistry of the compound and formation of soluble decomposition products during usage (Bala, et. al., 1998). The increasing interest of petrochemical industries in improving the performance of their products (gear lubricants, gasoline, among others) has been simultaneously generating great incentives in several research groups. The development of automotive engine lubricant additives derived from natural sources (cashew nut shell liquid - CNSL) is the main reason of interest, because they satisfy legislative and environmental demands (Green, et. al., 2003).

A lubricant consists of base oils and additives, so in the present investigation the authors used three kinds of mineral oils: hydrogenated naphthenic oils NH10, NH20 and NH140 (Technical regulation, ANP $\mathrm{N}^{\circ}$ 004/99) for evaluation of the antioxidant potential of the compounds synthesized. Studies of thiophosphorated additive performance in lubricating oil show that these products inhibit and intercept the deterioration by oxidation of organic species present in lubricants, especially at high temperatures and in the presence of air or metals (Ohgake, et. al., 1989).

*To whom correspondence should be addressed 
The shell of the cashew nut (Anacardium occidentale L.) contains alkyl-substituted phenolic compounds Internationally named CNSL, this oil is obtained as a by-product from mechanical processing for edible use of cashew kernel and its composition is a mixture of anacardic acid, cardanol and smaller amounts of cardol and 2-methylcardol (Attanasi, et. al., 2006) Figure 1. One of its highest-yield derivatives cardanol is currently being used as an antioxidant in the petrochemical industry (Trevisan, et. al., 2006) and such studies have more and more consolidated a research program based on green chemistry. Since cardanol is an important natural source of phenolic compounds and thus possesses antioxidant properties, many synthetic mechanisms involving this type of additive have been developed based on CNSL derivatives (Kuman, et. al., 2002; Paramashivappa, et. al., 2001).

Considering the great importance of this group of additives and their multifunctional properties (antioxidant, antiwear additive, extreme pressure additive, corrosion inhibitor) thiophosphorated compounds have not lost their dominant role as standard additives of modern tribology (Mang, et. al., 2001). In the present work we obtain an organothiophosphorus antioxidant based on hydrogenated cardanol and diethyl thiochlorophosphate. The synthesized compound was investigated using a classical thermoanalyticalthermogravimetric method (TG/DTG) parallel to NH10, NH20 and NH140 oils, in comparison with previous work (Rios, et. al., 2007).

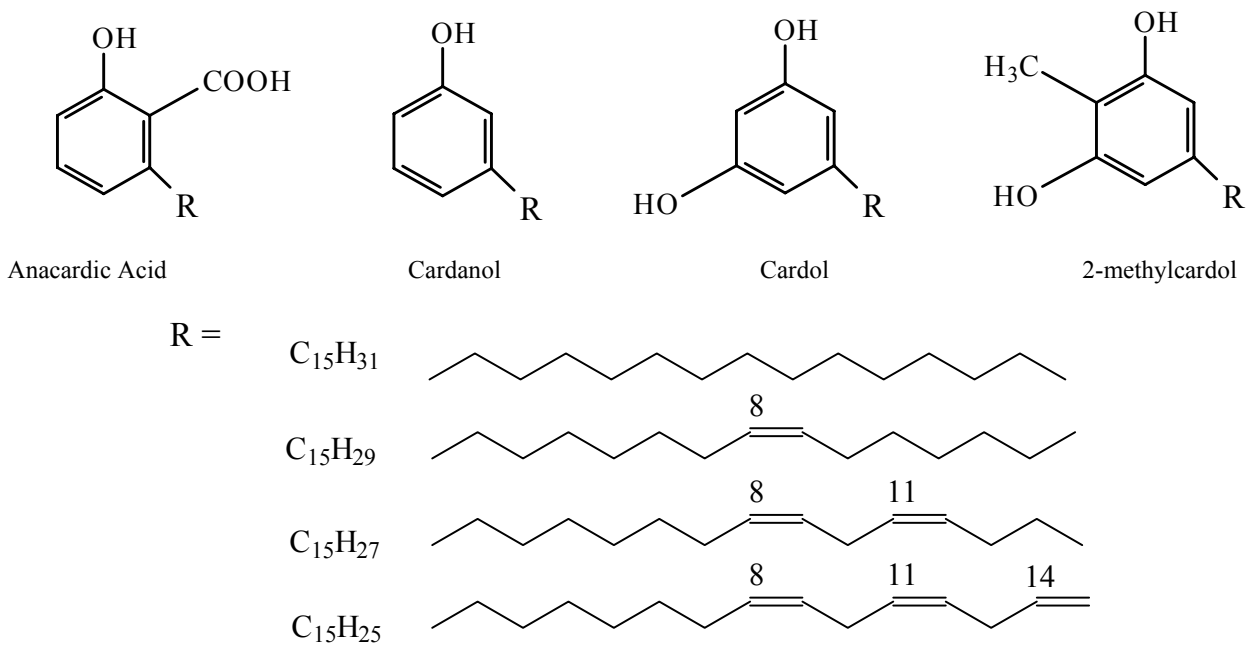

Figure 1: Structure of the constituents of CNSL

\section{MATERIALS AND METHODS}

\section{Materials}

Cashew nut shell liquid (CNSL) was supplied by Irmãos Fontenele S.A. Industry, (Fortaleza, Brazil). The hydrogenated cardanol used in this work is in accord with analytical analysis and literature data (Paramashivappa, et. al., 2001). The hydrogenated naphthenic oils NH10, NH20 and NH140 were supplied by Petrobras (Brazilian Oil Company, Brazil) with no further treatment procedure. The reagents and solvents were supplied by Aldrich (analytical grade).

\section{Product Analyses}

IR spectra were obtained by use of a FTIR spectrophotometer Perkin Elmer, mod. Spectrum one.

NMR $\left({ }^{1} \mathrm{H}\right.$ and $\left.{ }^{31} \mathrm{P}\right)$ spectra were recorded on an AVANCE DRX 500 BRUKER spectrometer, at a frequency of $500 \mathrm{MHz}$ under the following conditions: solvent, $\mathrm{CDCl}_{3}$; tetramethylsilane (TMS) as an internal standard for ${ }^{1} \mathrm{H}$ and phosphoric acid $\left(\mathrm{H}_{3} \mathrm{PO}_{4}\right)$ for ${ }^{31} \mathrm{P}$.

GC-MS analysis was carried out using a HewlettPackard 5890 and a Hewlett-Packard 5971A mass selective detector, on a dimethylpolysiloxane (DB-5) 
column. Sample of $1 \mu \mathrm{L}$ was injected into the column.

Thermoanalytical measurements were carried out using a SHIMADZU TGA-50H thermogravimetric analyzer. Thermogravimetric (TG) measurements were performed at a scanning rate of $10^{\circ} \mathrm{C} / \mathrm{min}$. Samples of approximately $10 \mathrm{mg}$ were heated from 30 to $700^{\circ} \mathrm{C}$. The measurements were carried out in a synthetic air atmosphere $(50 \mathrm{~mL} / \mathrm{min})$.

\section{Experimental Procedure}

CNSL was hydrogenated by catalytic hydrogenation (Castro Dantas, et. al, 2003; Avellar, et. al., 2000). The product was analyzed by GC-MS, ${ }^{1} \mathrm{H}$ and ${ }^{31} \mathrm{P}-\mathrm{NMR}$ and FTIR to prove the identity and purity of the hydrogenated cardanol.

The analysis by ${ }^{1} \mathrm{H}-\mathrm{NMR}$, showed the following $\left(\mathrm{C}_{3} \mathrm{D}_{6} \mathrm{O}, \mathrm{ppm}\right): 0.9,3 \mathrm{H}, \mathrm{R}-\mathrm{CH}_{3} ; 1.3,8 \mathrm{H},-\left(\mathrm{CH}_{2}\right)_{\mathrm{n}}-$; $1.5,9 \mathrm{H},-\left(\mathrm{CH}_{3}\right)_{3} ; 2.5,2 \mathrm{H},-\mathrm{CH}_{2}-\mathrm{Ar} ; 6.6,1 \mathrm{H}, \mathrm{Ar}-\mathrm{OH}$; 7.2, $1 \mathrm{H}, \mathrm{Ar}-\mathrm{H} ; 7.5,1 \mathrm{H}, \mathrm{Ar}-\mathrm{H}$; in accord with literature data (Castro Dantas, et. al, 2003; Koh, et.al., 1995).

FTIR spectral $\left(v, \mathrm{~cm}^{-1}\right)$ data were: $3412(\mathrm{OH})$; 2917 and $2849\left(\mathrm{CH}_{2}, \mathrm{CH}_{3}\right) ; 1619,1587$ e $1463(\mathrm{C}=\mathrm{C}$ aromatic ring vibrations); 747 (angular $\mathrm{C}-\mathrm{H}$ deformation of the aromatic ring), in accord with literature data (Castro Dantas, et. al, 2003; Koh, et.al., 1995).

The thiophosphorated compound was synthesized by an optimization of the method described in the literature (Lopes, 2005). A reflux system under constant agitation at $60^{\circ} \mathrm{C}$ and inert atmosphere was used, because of the intermoleculecular migration of $\mathrm{P}-\mathrm{O}-\mathrm{R}$ to $\mathrm{P}-\mathrm{S}-\mathrm{R}$, sulphur transfer and oxidation of $\mathrm{P}=\mathrm{S}$ to $\mathrm{P}=\mathrm{O}$ can take place during thermal degradation (Bansal, et.al., 2002). The stoichiometric ratio of the reaction system was $1.0 \mathrm{~mol}$ of hydrogenated cardanol/1.0 mol of sodium hydroxide/1.0 mol of diethyl thiochlorophosphate, respectively. After the reaction time of $9 \mathrm{~h}$ viscous orange oil was obtained. The obtained product was purified by column chromatography followed by its characterization using ${ }^{1} \mathrm{H}$ and ${ }^{31} \mathrm{P}-\mathrm{NMR}$, FTIR and GC-MS. (Lopes, 2005; Attanasi et.al., 1995)

Thermal-oxidative stability studies were carried out using thermoanalytical measurements (TG/DTG).

\section{RESULTS AND DISCUSSION}

\section{Characterization}

The characterization of the synthesized product (thiophosphorated cardanol derivative) is summarized below.

NMR ${ }^{1} \mathrm{H},\left(\mathrm{CDCl}_{3}, \mathrm{ppm}\right)$ data were: $0.9,3 \mathrm{H}$, $\mathrm{R}-\mathrm{CH}_{3} ; 1.4-1.3,2 \mathrm{H},-\mathrm{CH}_{2} ; 2.6,2 \mathrm{H},-\mathrm{CH}_{2}-\mathrm{Ar} ; 4.4-$ $4.2,2 \mathrm{H}, 3 \mathrm{H}, \mathrm{CH}_{3} \mathrm{CH}_{2} \mathrm{O}-; 7.0,1 \mathrm{H}, 2 \mathrm{H}, \mathrm{H}_{1}-\mathrm{H}_{2}-\mathrm{Ar}$; 7.3, $\mathrm{H}_{3}-\mathrm{Ar}$.

NMR ${ }^{31} \mathrm{P}(\mathrm{ppm}): 64, \mathrm{P}, \mathrm{S}=\mathrm{P}-\mathrm{O}$.

FTIR spectra $\left(v, \mathrm{~cm}^{-1}\right): 2923$ and $2853\left(\mathrm{CH}_{2}\right.$, $\left.\mathrm{CH}_{3}\right) ; 1608$ and $1443(\mathrm{C}=\mathrm{C}$ aromatic ring vibrations); 1239 (Ar-O aromatic vibrations); 1147 $\left(\mathrm{P}-\mathrm{O}-\mathrm{C}_{2} \mathrm{H}_{5}\right) ; 1015$ (P-O-C aliphatic) 963 (P-O-Ar); $792(\mathrm{P}=\mathrm{S}) ; 733$ (angular $\mathrm{C}-\mathrm{H}$ deformation of the aromatic ring).

GC-MS profile shows the appearance of a characteristic peak confirming the purity of the thiophosphorated compound $(456 \mathrm{~g} / \mathrm{mol})$.

Figure 2 shows the structures of hydrogenated cardanol and thiophosphorated cardanol.

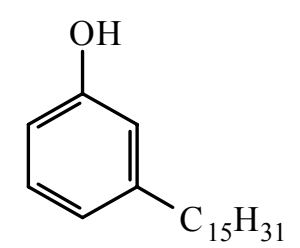

Hydrogenated

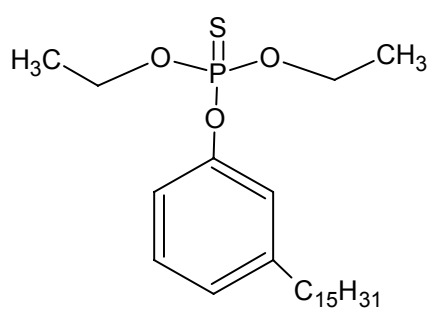

Thiophosphorated

Figure 2: Structures of hydrogenated and thiophosphorated cardanol. 


\section{Thermal-oxidative stability studies}

\section{a) Hydrogenated, Phosphorated and Thiophosphorated}

The thiophosphorated compounds are typical peroxide decomposers and numerous types of sulphur-phosphorus have been evaluated as antioxidants (Mang, et. al., 2001), so the present work studied the antioxidant potentiality of the synthesized compound by thermogravimetric analysis or TG. This type of testing that is performed on samples to determine the mass loss of a particular sample versus time or temperature is very useful for the evaluating additive performance of organic materials. The degradation starting points of the materials observed by TG/DTG can provide data regarding events of mass loss with temperature at which these events are most significant (Rios, 2007).

Previous to the TG of compound, the authors began the analyses of thermal-oxidative stability of hydrogenated cardanol, Figure 3. The TG curve showed a simple degradation step starting at $200^{\circ} \mathrm{C}$ and ending at $320^{\circ} \mathrm{C}$ due to probably to the loss of aliphatic and aromatic hydrocarbon groups, Table 1. A comparative thermal study of phosphorated and thiophosphorated cardanol compounds is given in
Figure 4. The phosphorated compound showed an initial degradation at $56^{\circ} \mathrm{C}$ finishing at $159^{\circ} \mathrm{C}$ probably due to volatile products $(5 \mathrm{wt} \%)$ remained from the synthesis reaction. The second degradation step observed at $174^{\circ} \mathrm{C}$ and finished at $350^{\circ} \mathrm{C}$ was a complex mechanism with superposition of three different events $(83 \mathrm{wt} \%)$. The maximum degradation rate of the main degradation event was observed at $290^{\circ} \mathrm{C}$. The residue of $12 \%$ (wt \%) was attributed to inorganic material (phosphorus), Table 2.

The TG curve of thiophosphorated compound showed five steps of degradation, Figure 5 . The first initial degradation step occurs at $25^{\circ} \mathrm{C}$ finishing at $160^{\circ} \mathrm{C}$ probably due to loss of water, because of hydrophilicity of the sulfur atom $(13 \mathrm{wt} \%)$. The second degradation step observed at $230^{\circ} \mathrm{C}$ and finished at $310^{\circ} \mathrm{C}$ was a complex mechanism with superposition of different events $(42 \mathrm{wt} \%)$. The maximum degradation rate of the main degradation event was observed at $285^{\circ} \mathrm{C}$. The third degradation step observed at $320^{\circ} \mathrm{C}$ and finished at $350^{\circ} \mathrm{C}$ showed of mass loss of $11 \mathrm{wt} \%$ the fourth and fifth steps were less significant steps and are given in Table 3. The residue of 5\% (wt \%) was attributed to inorganic material (phosphorus). Table 4 shows the thermoanalytical comparative data of two derivative compounds.

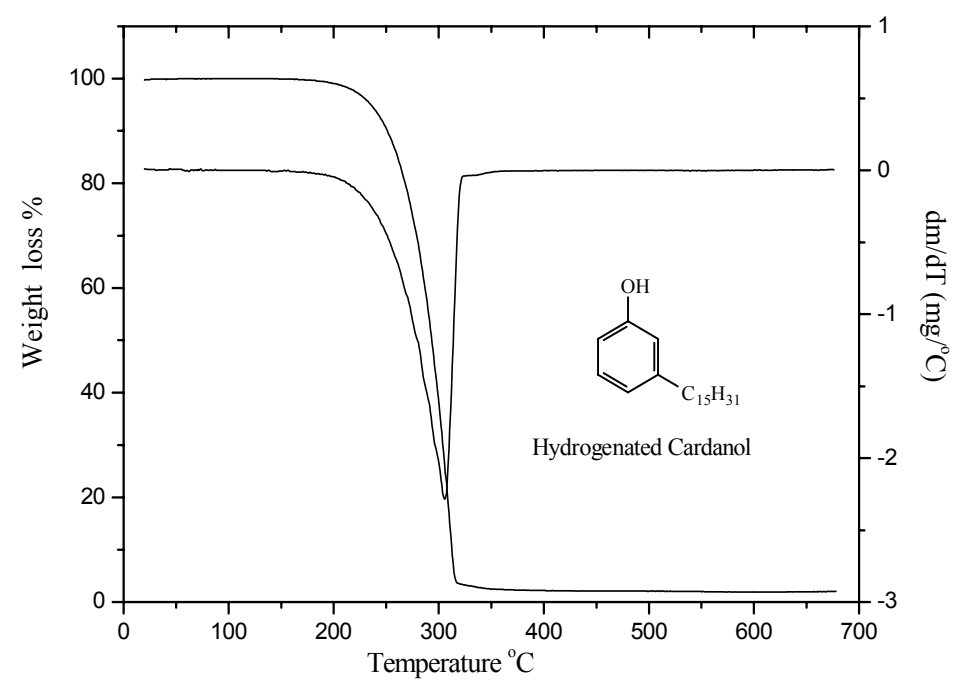

Figure 3: TG/DTG curve of hydrogenated cardanol.

Table 1: Thermal degradation data of hydrogenated cardanol.

\begin{tabular}{|c|c|c|c|c|c|c|}
\hline Sample & $\begin{array}{c}\text { Degradation } \\
\text { step }\left(\mathbf{n}^{\circ}\right)\end{array}$ & & $\begin{array}{l}\text { radat } \\
\text { ratur }\end{array}$ & & $\begin{array}{c}\text { Mass loss } \\
(\mathrm{wt} \%)\end{array}$ & $\begin{array}{c}\text { Residue } \\
(\mathbf{w t} \%)\end{array}$ \\
\hline \multirow{2}{*}{ Hydrogenated cardanol } & \multirow[t]{2}{*}{ - } & $\mathbf{T}_{\mathbf{i}}$ & $\mathbf{T}_{\mathrm{f}}$ & $\mathbf{T}_{\max }$ & \multirow[b]{2}{*}{96} & \multirow[t]{2}{*}{$2=$} \\
\hline & & 200 & 320 & 250 & & \\
\hline
\end{tabular}




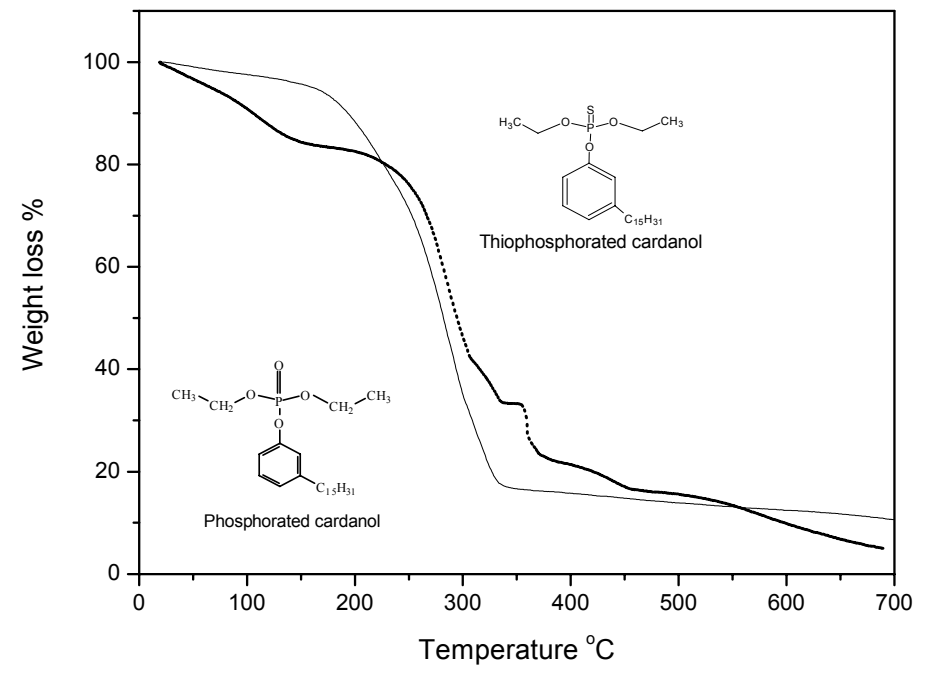

Figure 4: TG curves of phosphorated and thiophosphorated cardanol derivatives.

Table 2: Thermal degradation data of phosphorated cardanol.

\begin{tabular}{|c|c|c|c|c|c|c|}
\hline Sample & $\begin{array}{c}\text { Degradation } \\
\text { step }\left(n^{0}\right)\end{array}$ & \multicolumn{3}{|c|}{$\begin{array}{c}\text { Degradation } \\
\text { temperature }\left({ }^{\circ} \mathrm{C}\right)\end{array}$} & $\begin{array}{c}\text { Mass loss } \\
(\mathbf{w t} \%)\end{array}$ & $\begin{array}{c}\text { Residue } \\
\text { (wt\%) }\end{array}$ \\
\hline \multirow[b]{2}{*}{ Phosphorated cardanol } & & $\mathbf{T}_{\mathbf{i}}$ & $\mathbf{T}_{\mathrm{f}}$ & $T_{\max }$ & & \multirow[b]{2}{*}{12} \\
\hline & $\begin{array}{r}\text { I } \\
\text { II }\end{array}$ & $\begin{array}{r}56 \\
174\end{array}$ & $\begin{array}{l}159 \\
350\end{array}$ & $\begin{array}{c}- \\
290\end{array}$ & $\begin{array}{r}5 \\
83\end{array}$ & \\
\hline
\end{tabular}

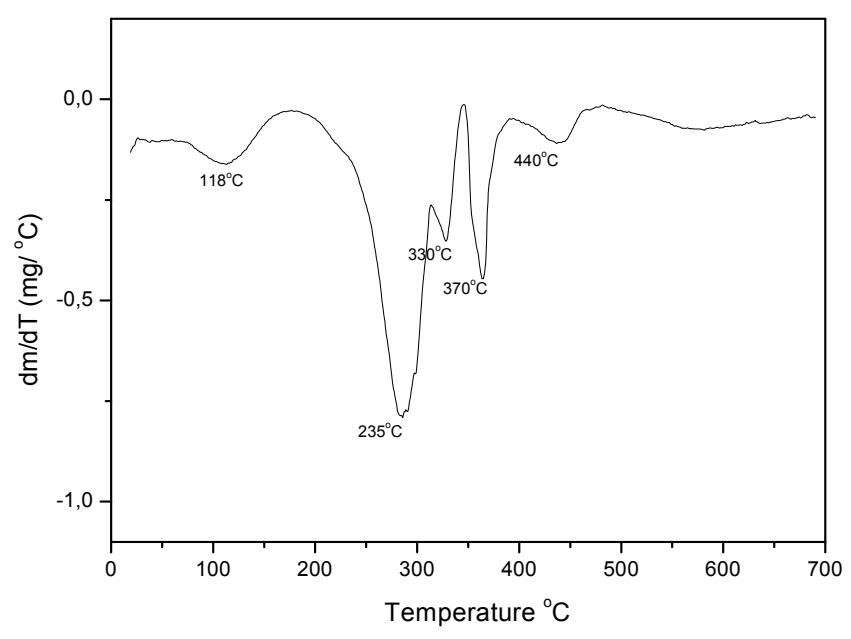

Figure 5: DTG curve of thiophosphorated cardanol.

Table 3: Thermal degradation data of thiophosphorated cardanol.

\begin{tabular}{|c|c|c|c|c|c|c|}
\hline \multirow{2}{*}{ Sample } & \multirow{2}{*}{$\begin{array}{l}\text { Degradation } \\
\text { step }\left(\mathbf{n}^{\circ}\right)\end{array}$} & \multicolumn{3}{|c|}{$\begin{array}{c}\text { Degradation } \\
\text { temperature }\left({ }^{\circ} \mathrm{C}\right)\end{array}$} & \multirow{2}{*}{$\begin{array}{l}\text { Mass loss } \\
(\mathbf{w t} \%)\end{array}$} & \multirow{2}{*}{$\begin{array}{c}\text { Residue } \\
\text { (wt\%) }\end{array}$} \\
\hline & & $\mathbf{T}_{\mathbf{i}}$ & $\mathbf{T}_{\mathrm{f}}$ & $T_{\max }$ & & \\
\hline \multirow{5}{*}{ Thiophosphorated cardanol } & I & 25 & 160 & 110 & 13 & \multirow{5}{*}{5} \\
\hline & II & 230 & 310 & 285 & 42 & \\
\hline & III & 320 & 350 & 330 & 11 & \\
\hline & IV & 360 & 380 & 370 & 12 & \\
\hline & V & 400 & 450 & 440 & 17 & \\
\hline
\end{tabular}


Table 4: Thermoanalytical comparative data of thiophosphorated and phosphorated compounds in NH10, NH20 and NH140 oils.

\begin{tabular}{|c|c|c|c|c|}
\hline \multirow{2}{*}{$\begin{array}{l}\text { Hhydrogenated } \\
\text { Naphthenics Oils }\end{array}$} & \multicolumn{2}{|c|}{$\begin{array}{c}\mathbf{T}_{\text {MAX }}\left({ }^{0} \mathbf{C}\right) \\
\text { Thiophosphorated cardanol }\end{array}$} & \multicolumn{2}{|c|}{$\begin{array}{c}\mathbf{T}_{\text {MAX }}\left({ }^{0} \mathbf{C}\right) \\
\text { Phosphorated cardanol }\end{array}$} \\
\hline & $\begin{array}{c}0 \\
(w t \%)\end{array}$ & $\begin{array}{c}1.2 \\
(w t \%)\end{array}$ & $\begin{array}{c}0 \\
(w t \%)\end{array}$ & $\begin{array}{c}1.2 \\
(w t \%)\end{array}$ \\
\hline NH10 & 251 & 255 & 256 & 278 \\
\hline NH20 & 250 & 265 & 262 & 290 \\
\hline $\mathrm{NH} 140$ & 300 & 310 & 340 & 340 \\
\hline
\end{tabular}

\section{b) Hydrogenated Naphthenics Oils - NH10, NH20 and NH140}

Figure 6 shows the TG/DTG curves of hydrogenated naphthenics oil (NH10). The oil showed a simple degradation step starting at $100^{\circ} \mathrm{C}$ and ending at $289^{\circ} \mathrm{C}$ due probably to loss of organic material $(99 \%)$. The maximum degradation rate was observed at $251^{\circ} \mathrm{C}$.

Similar degradation profile TG/DTG curves were observed for NH10 oil after addition of 1.2\% (wt\%) of thiophosphorated cardanol compound. However, the temperature of the maximum degradation rate was shifted to higher value $\left(255^{\circ} \mathrm{C}\right)$, Figure 7 , Table 5 .

The NH20 oil showed a simple degradation step starting at $133^{\circ} \mathrm{C}$ and ending at $305^{\circ} \mathrm{C}$ probably due to loss of organic material $(99 \mathrm{wt} \%)$, Figure 8 . The maximum degradation rate was observed at $250^{\circ} \mathrm{C}$.

The onset temperatures in oils containing the thiophosphorated compound were shifted to higher temperatures as compared with the absence of additive, Figure 9 shows the TG/DTG curve of NH20 oil after addition of $1.2 \%$ (wt $\%$ ) of thiophosphorated cardanol compound. It proves that the presence of thiophosphorated compound in the oil improves the oxidative stability as given in Table 6. Figure 10 shows the TG/DTG curves of NH140 oil and Figure 11 shows the curves after addition of $1.2 \%$ (wt $\%$ ) of additive. Data are given in Table 7, and the degradation was shifted to higher temperature when compared with $\mathrm{NH} 140$ oil without additive.

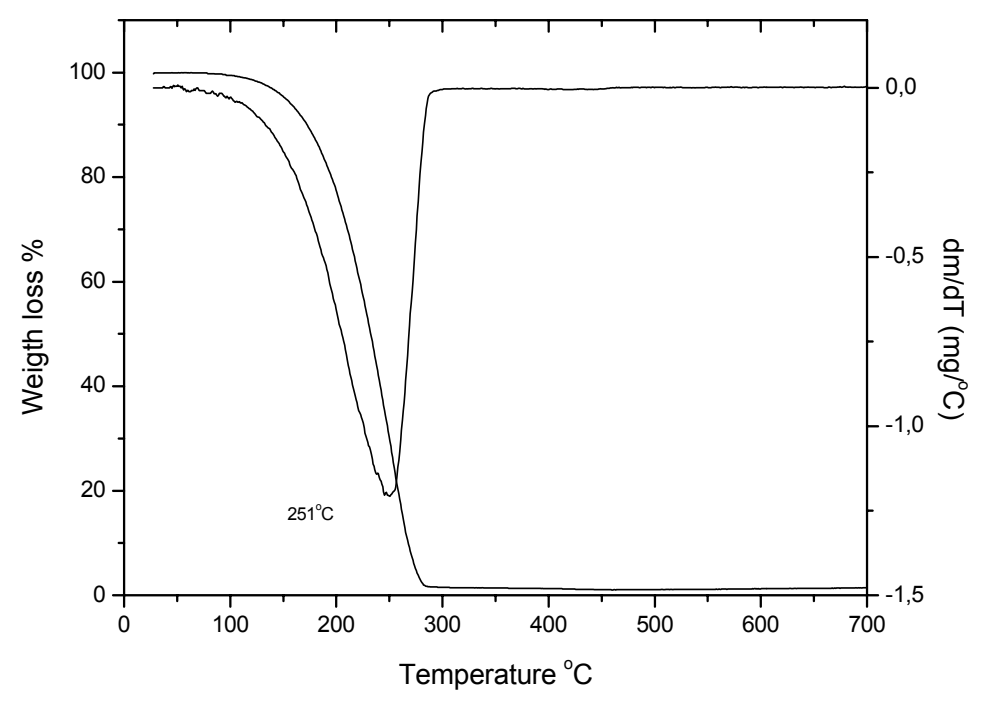

Figure 6: TG/DTG curves of NH10 oil.

Table 5: Thermal degradation data of NH10 oil with and without additive (1.2 wt\% of thiophosphorated cardanol).

\begin{tabular}{|c|c|c|c|c|c|c|}
\hline Sample & $\begin{array}{c}\text { Degradation } \\
\text { step }\left(\mathbf{n}^{0}\right)\end{array}$ & \multicolumn{3}{|c|}{$\begin{array}{c}\text { Degradation } \\
\text { temperature }\left({ }^{\circ} \mathrm{C}\right)\end{array}$} & $\begin{array}{c}\text { Mass loss } \\
(w t \%)\end{array}$ & $\begin{array}{c}\text { Residue } \\
(\mathrm{wt} \%)\end{array}$ \\
\hline & & $\mathbf{T}_{\mathbf{i}}$ & $\mathbf{T}_{\mathrm{f}}$ & $\mathbf{T}_{\max }$ & & \\
\hline NH10 oil & I & 100 & 289 & 251 & 99 & 1 \\
\hline NH10 oil with additive & I & 114 & 290 & 255 & 99 & 1 \\
\hline
\end{tabular}




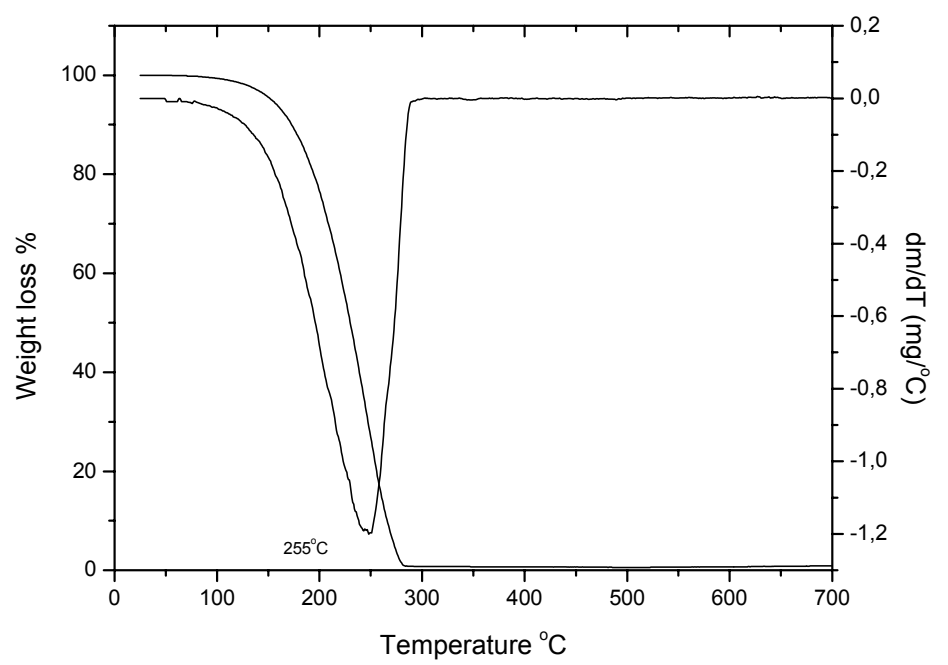

Figure 7: TG and DTG curves of NH10 oil with 1.2\% of thiophosphorated cardanol.

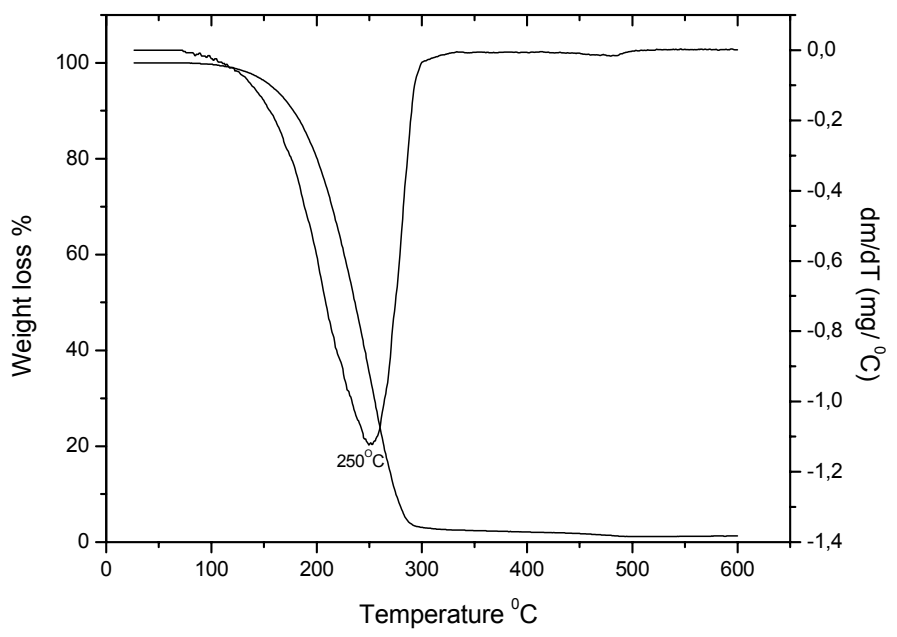

Figure 8: TG and DTG curves of NH20 oil.

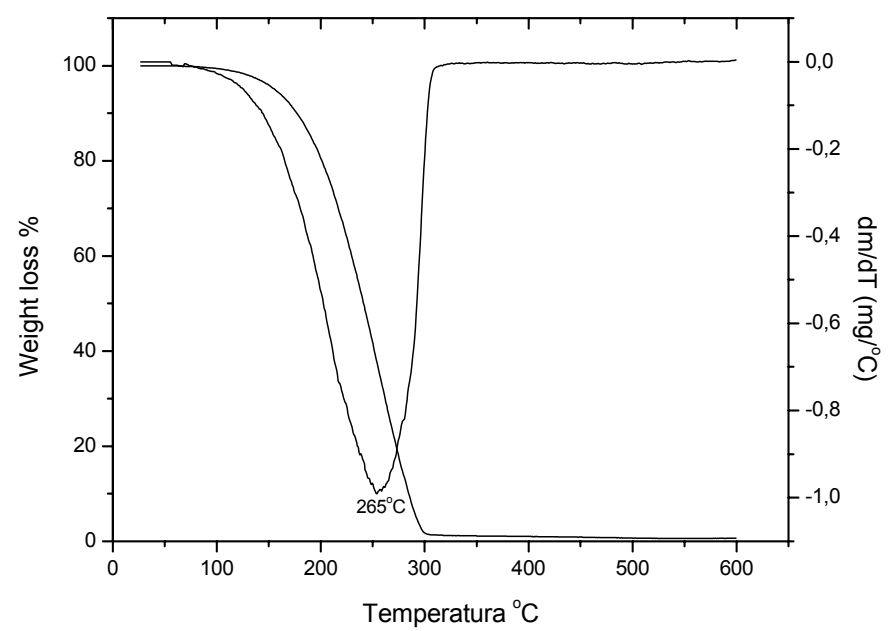

Figure 9: TG and DTG curves of NH20 oil with $1.2 \%$ of thiophosphorated cardanol. 
Table 6: Thermal degradation data of $\mathrm{NH20}$ oil with and without additive (1.2 wt\% of thiophosphorated cardanol).

\begin{tabular}{|c|c|c|c|c|c|c|}
\hline Sample & $\begin{array}{c}\text { Degradation } \\
\text { step }\left(\mathbf{n}^{\circ}\right)\end{array}$ & \multicolumn{3}{|c|}{$\begin{array}{c}\text { Degradation } \\
\text { temperature }\left({ }^{\circ} \mathrm{C}\right)\end{array}$} & $\begin{array}{c}\text { Mass loss } \\
(\mathrm{wt} \%)\end{array}$ & $\begin{array}{l}\text { Residue } \\
(\mathbf{w t} \%)\end{array}$ \\
\hline & & $\mathbf{T}_{\mathbf{i}}$ & $T_{f}$ & $\mathbf{T}_{\max }$ & & \\
\hline NH20 oil & I & 133 & 305 & 250 & 99 & 1 \\
\hline NH20 oil with additive & I & 135 & 315 & 265 & 100 & - \\
\hline
\end{tabular}

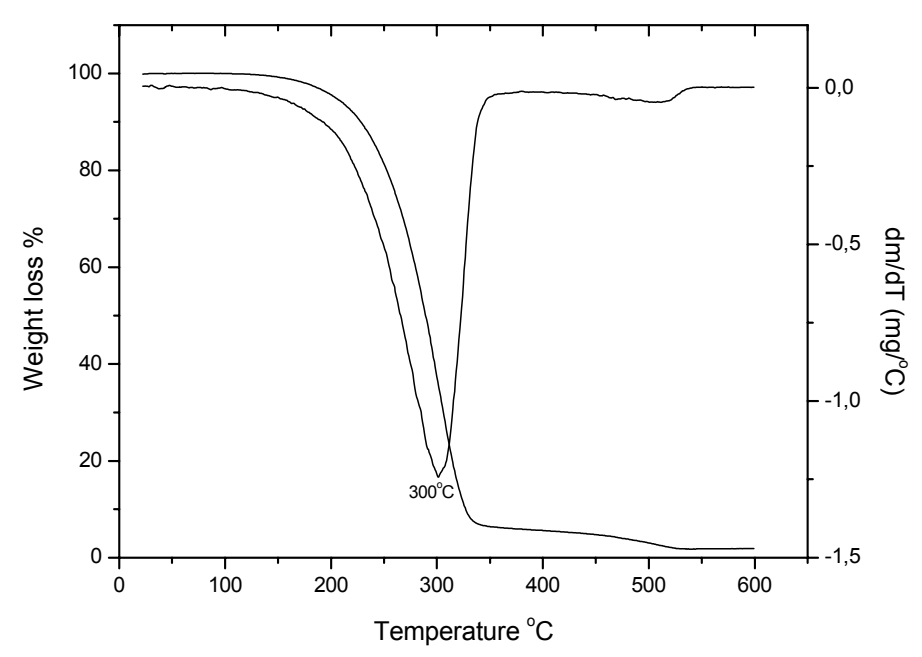

Figure 10: TG and DTG curves of NH140 oil

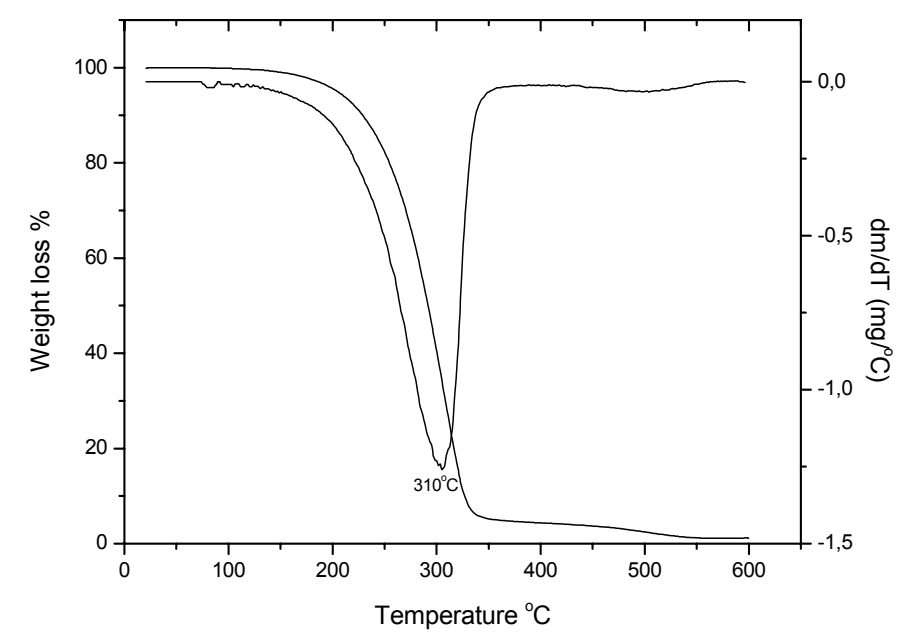

Figure 11: TG and DTG curves of NH140 oil with 1.2\% of thiophosphorated cardanol.

Table 7: Thermal degradation data of NH140 oil with and without additive (1.2 wt\% of thiophosphorated cardanol).

\begin{tabular}{|c|c|c|c|c|c|c|}
\hline Sample & $\begin{array}{l}\text { Degradation } \\
\text { step }\left(\mathbf{n}^{0}\right)\end{array}$ & \multicolumn{3}{|c|}{$\begin{array}{c}\text { Degradation } \\
\text { temperature }\left({ }^{\circ} \mathrm{C}\right)\end{array}$} & $\begin{array}{c}\text { Mass loss } \\
(w t \%)\end{array}$ & $\begin{array}{c}\text { Residue } \\
\text { (wt\%) }\end{array}$ \\
\hline \multirow{3}{*}{$\begin{array}{l}\text { NH140 oil } \\
\text { NH140 oil with additive }\end{array}$} & \multirow{3}{*}{$\begin{array}{l}\text { I } \\
\text { I }\end{array}$} & $T_{i}$ & $T_{f}$ & $\mathbf{T}_{\max }$ & \multirow{3}{*}{$\begin{array}{l}98 \\
99\end{array}$} & \multirow{3}{*}{$\begin{array}{l}2 \\
1\end{array}$} \\
\hline & & 175 & 350 & 300 & & \\
\hline & & 185 & 356 & 310 & & \\
\hline
\end{tabular}




\section{CONCLUSIONS}

Addition of phosphorus and phosphorus-sulfur compounds to hydrogenated naphthenic oils provides superior thermal stability for lubricants, greases and fuels and/or superior functionalized lubricants with multifunctional properties. In this work, we studied the antioxidant potentiality of two synthesized molecules - thiophosphorated and phosphorated compounds from hydrogenated cardanol which presented even better stability. The addition of specific amounts of synthesized compounds in $\mathrm{NH} 10, \mathrm{NH} 20$ and $\mathrm{NH} 140$ oils improves their thermal-oxidative stability by $5-15^{\circ} \mathrm{C}$. The occurrence of major thermal degradation events at higher temperatures $\left(\mathrm{T}_{\max }\right)$ for additivated hydrogenated naphthenics oils (Mascolo et. al., 2005) retarding their thermal degradation process, is an excellent indication of the antioxidant properties of the thiophosphorated and phosphorated cardanol compounds (Haines, 1995).

\section{REFERENCES}

Bansal,V., Dohhen, K.C., Sarin, R., Sarpal, A.S., Bhatnagar, A.K., Sulphur-phosphous components in gear oils. Part 1, oxidation stability studies by [31]P-NMR spectroscopic techniques. Tribology International, 35, pp. 819-828 (2002).

Lopes, A.A.S., Síntese de um Aditivo Tiofosforado a partir do Líquido da Casca da Castanha de Caju (Anacardium occidentale Linn) Dissertation (Master). Universidade Federal do Ceará: CE, Brazil; (2005).

Bala, V., Saathaff, L., Oxidative stability of automotive gear lubricants. NLGI Spokesman, 12 (12), (1998).

Green, J. H., Morina, A., Priest, M., Neville,A., Lubricant Additive Interactions, Surface Reactions and the Link to Tribological Performance in Engines. Institute of Tribology, School of Mechanical Engineering, University of Leeds. (2003).

Technical Regulations ANP No 004/99 (1999).

Ohgake, R., Sunami, M., Yoshida T., Watanabe, H., ASTM Special Techn. Publ. 32, (1989).
Attanasi,O., Berretta, S., Fiani, C., Filippone,P., Mele, G., Saladino,R., Synthesis and reactions of nitro derivativesof hydrogenated cardanol. Tetrahedron 62, pp. 6113-6120 (2006).

Trevisan M T, Pfundstein B, Haubner R, Würtele G, Spiegelhalder B, Bartsch H, Owen R W. Characterization of alkyl phenols in cashew (Anacardium occidentale) products and assay of their antioxidant capacity. Food Chem Toxicol, 44, pp.118-197 (2006).

Kumar, P. P., Paramashivappa, R., Vithayathil, P. J., Rao, P. V. S., Rao, A. S., Process for Isolation of Cardanol from Technical Cashew (Anacardium occidentale L.) Nut Shell Liquid. J Agric Food Chemistry, 50, pp.4705-4708 (2002).

Paramashivappa, R., Kumar,P. P., Vithayathil, P. J., Rao, A. S., Novel Method for Isolation of Major Phenolic Constituents from Cashew (Anacardium occidentale L.) Nut Shell Liquid. J Agric Food Chemistry, 49, pp. 2548-2551 (2001)

Mang,T., Dresel,W., Lubricants and Lubrications, Wiley-VCH, Weinheim, New York (2001).

Rios, M.A.F., Mazzetto, S.E., Carioca,J.J.B., Barros, G.G., Evaluation of antioxidant properties of a phosphorated cardanol compound on mineral oils (NH10 and NH20). Fuel, accepted for publication (2007).

Dantas, T. N., Dantas, M. S. G., Dantas Neto, A. A., D'Ornellas, C. V., Queiroz, L. R., Novel antioxidants from cashew nut shell liquid applied to gasoline stabilization. Fuel, 82, pp.1465-1469 (2003).

Koh, C. S., Butt, J. B., Experimental and Modeling Study of Kinetics and Selectivity in the Oxidation of a Poly ( $\alpha$-olefin) Lubricant. Ind. Eng. Chem. Res., 34 pp.524-535 (1995).

Attanasi O, Filippone P, Grossi M. Synthesis of Some Phosphorus Derivatives of Cardanol. Phosp. Súlfur, 35, pp. 63-65 (1998).

Mascolo G, Rausa R, Bagnuolo G, Mininni G, Tinucci L. Thermal degradation of synthetic lubricants under oxidative pyrolytic conditions. J Anal Appl Pyrolysis, 75, pp. 167-1773 (2005).

Haines P J., Thermal Methods of Analysis Principles, Applications and Problems. London: Blackie Academic \& Professional (1995). 